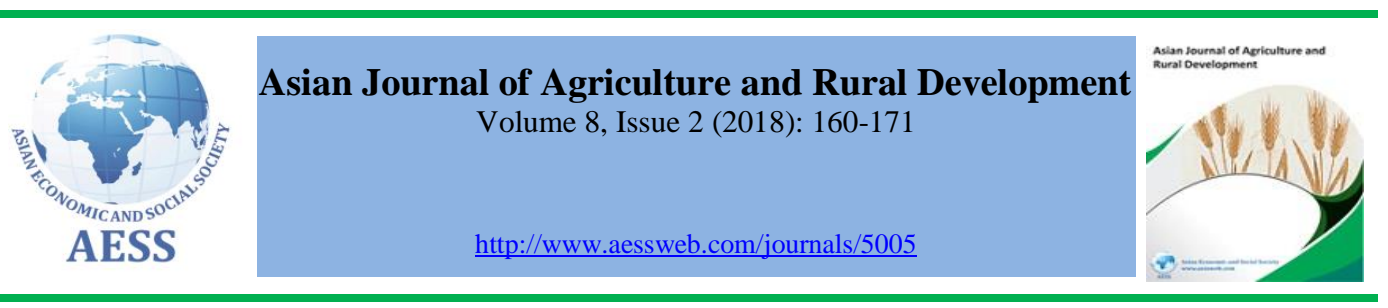

\title{
EFFECT OF UNDERSTUMPS AGE ON THE GROWTH OF BUDDING OF ORANGE PLANT (CITRUS SP.)
}

Salamet Ginandjar Department of Agrotechnology, Faculty of Science

\section{Subandi}

Alamsyah

Dikayani

\section{ARTICLE HISTORY:}

Received: 10-Aug-2018

Accepted: 02-Jan-2019

Online Available: 24-Jan2019

Keywords:

Budding,

Insert,

Chip-budding,

Orange and Technology, The State Islamic University of Sunan Gunung Djati of Bandung, Indonesia

\salametginandjar@uinsgd.ac.id (Corresponding author)

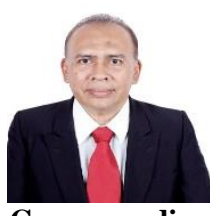

Corresponding author

ABSTRACT
The research was conducted in the Garden of Development of
Horticultural Seeds of West Java Province. The purpose of research to
know the influence of age of rootstock and budding method to the
success of citrus (Citrus sp). Research method using Factorial
Randomized Block Design (RBD) with 2 factors. The first factor is
the age of the Understump (rootstock) consisting of 5 levels, namely
the stem age of $4,6,8,10$ and 12 months, while the second factor is
the budding method consisting of 2 levels, namely T (T-budding)
budding method and the budding (Chip-budding). The results showed
that the treatment of budding method and the age of rootstock did not
interact in all observation variables. The treatment of budding method
and the age of rootstock independently had a very significant effect on
the high percentage of shoots, no significant effect on the stem bud
diameter and significantly affect the number of leaves. The best
treatment on the method of budding is the method of Insert (Chip-
Budding), while at the lowest rootstock is the best age of rootstock 6
months.

\section{Contribution/ Originality}

The current study analyse the influence of age of rootstock and budding method to the success of citrus (Citrus sp) using Factorial Randomized Block Design (RBD) with 2 factors in the Garden of Development of Horticultural Seeds of West Java Province.

DOI: 10.18488/journal.1005/2018.8.2/1005.2.160.171

ISSN (P): 2304-1455/ISSN (E):2224-4433

How to cite: Salamet Ginandjar, M. Subandi, Alamsyah and Dikayani (2018). Effect of understumps age on the growth of budding of orange plant (Citrus sp.). Asian Journal of Agriculture and Rural Development, 8(2), 160-171.

(C) 2018 Asian Economic and Social Society. All rights reserved. 


\section{INTRODUCTION}

Oranges can be consumed in fresh or processed form with protein content of $0.5 \mathrm{~g}, 0.1 \mathrm{~g}$ fat, 500 to $1000 \mathrm{~g}$ of vitamin $\mathrm{C}$ and carbohydrate $20 \mathrm{~g}$. Indonesia has made oranges into industrial products such as: leather oil and orange seeds, alcohol, sugar drops and pectin from waxed oranges. Oil from orange peel is used for perfume, soap and cake mixture. Oranges are used as traditional medicine, such as fever, pain reliever and for inflammation of the eyes (Buton, 2010).

Orange is one of the fruits commodities that have an important role in the world market and in the country, because it has a high economic value, the government not only directs the management of oranges for small farmers, but also oriented to the development of a comprehensive citrus industry.

A brighter prospect toward orange agribusiness is becoming more real with attention to various potentials such as the potential of land that is the availability of agricultural land for fruit crops covering millions of hectares so it has a big enough opportunity to open large scale plantations with attention to the suitability of agroclimate, the potential of production can be is achieved if the management of citrus farming is done intensively to lead to agribusiness, and the market potential is predicted that the demand for citrus fruits will increase with increasing income, population growth and income elasticity on demand (Soelarso, 1996).

Successful exploitation of fruit crops, especially large-scale commercial ones is determined by the availability of quality seeds at the right time, in large quantities at affordable prices by farmers. The use of unsuitable seeds and varieties will lead to difficulties in subsequent crop management. This mistake will usually be felt several years later after the plant produces (Hatta et al., 1992; Subandi et al., 2018; Obinna-Echem and Torporo, 2018). Therefore research and development and management of existing nurseries needs to be improved to meet growing consumer demand for seedlings (Samekto et al., 1995; Subandi et al., 2017; Mukadasi, 2018).

Commercial cultivated citrus plants generally use seeds derived from budding (Samson, 1980).

\subsection{Budding}

Oculation is a plant propagation technique by combining good seedlings from the upper stem and rootstock. Implementation will occur with the upper and lower stem links through a two-stage process, which enlarges and divides the new cambium cell connecting the upper and lower root cultivars, the formation of vascular tissue that drains nutrients and water from the rootstock to the upper stem, the new and vascular cambium cells (Yuniastuti et al., 1992).

Pratomo et al. (2010) states that the connection between two harmonious plants will produce strong and long-lived plants. Furthermore Nurzaini (1997) reported that factors affecting budding are plant physiology, rootstock health, undercutaneous skin condition, climate at the time of budding, as well as technical factors such as skills and expertise in the implementation of the budding and the equipment used.

According to Devy and Jati (2008) in Suharsi and Sari (2013), rootstocks are crucial to the growth of citrus seedlings, as they are able to exploit unfavorable environmental conditions of drought, excess water, and resistance to certain pests and diseases. The rootstock of the rough lemon (RL) species has good rooting features for rocky and less fertile ground.

The age of the rootstock is thought to have an effect on the success of budding and growth of seedlings. The rootstock that is too young will be easy to lose water so that when the budding of the seedlings will wilt, otherwise if the rootstock used is too old, it is known that the old plant tissue has low regeneration power so that the connecting of the upper stem and rootstock is not 
perfect (Barus, 2000). According to Prastowo and Roshetko (2006) in Sugiatno and Hamim (2009), the rootstock requirement for the connection is 3-5 mm in diameter and 3-4 months.

The age of the rootstock affects the linking process between the upper and lower stems. From Prasetyo (2009) results, the fastest budding shoot growth was obtained from Japanese citroen (JC) rootstock 12 months old compared to younger and older age.

The technique of plant budding is the incorporation of the upper stem and the rootstock of two different plant species. The upper stem is expected for the development and growth of branch, tunasserta high fruit production with good quality. The rootstock is expected for the development of a robust root system, able to adapt to infertile soil conditions and to soil diseases. The grafted plant is expected to have superior properties possessed by the upper stem and rootstock (Susanto et al., 2004).

Propagation of citrus plants by budding should be done at the time of the plant at a generative growth stage. This technology will produce plants that are rapidly flowering and fruiting. The advantage of budding technology is that entres are used less because it only takes one bud to produce one seed. In addition, the implementation is faster and economical if there is a large rootstock. Some variations of the budding propagation technique are T-budding and Chip-budding modification. The choice of method depends on several considerations: plant type, upper stem and rootstock condition, material availability, propagation purposes, equipment and expertise workers (Limbongan and Limbongan, 2012) in Limbongan and Djufry (2013).

\subsection{The T method (T-budding)}

According to Limbongan and Limbongan (2012) Method T or $\perp$ (T inverted) is a budding method in which the incision on the rootstock resembles the letter $\mathrm{T}$ or $\perp$ ( $\mathrm{T}$ inverted), the stem diameter has reached 3-5 mm and the growth of the rootstock is quite active, easily removed from the wood.

\subsection{Insert method (Chip-budding)}

Chip Budding method is an budding method where the rootstock is slashed along 1-2 cm so that the wood and the skin is taken or the incision of the rootstock can be said to form the same notch with the slices of the temple's eye, so that when it is grafted entres and the wood is attached (Limbongan and Limbongan, 2012).

\section{METHODOLOGY}

\subsection{Place and time of research}

The place of research was carried out in the garden of Horticultural Seed Development Center. Department of Agriculture Food Crop West Java Province. Implementation of the research in April-June.

\subsection{Materials and tools}

The materials used in the research are local citrus seedlings JC (Japanche citroen) as rootstock and the top stem used is local orange Siam Banjar. While the tool used is the knife budding, cutting scissors, plastics, labels, cutter, hygrometer, plugs, ruler, soil (latosol) and stationery.

\section{RESULTS AND DISCUSSION}

\subsection{Temperature and humidity}

Temperature and humidity are factors that can affect the growth and development of plants and microbes that exist. Temperature and humidity affect each other, too. In general, the higher the temperature the lower air humidity and vice versa. The low temperature and humidity around the 
plant are influenced by sunlight and plant density. Observation data of temperature and humidity that is average temperature $19^{\circ} \mathrm{C}-25^{\circ} \mathrm{C}$ and humidity with average $77 \%-78 \%$. So that environmental provide optimal condition for healing process of the bud tissue wound. Supriyanto and Setiono (2006) stated that the optimal growing environment is needed for healing tissue wound, healing process of the rootstock seedlings. Oxygen, temperature, and humidity play important role in regulating the networking pooling process. Oxygen requirement can be fulfilled by way of fastening budding which is not too tight, optimal temperature range between $20^{\circ} \mathrm{C}$ $30^{\circ} \mathrm{C}$, air humidity is maintained above $70 \%$. Sutami and Gusti (2009) stated the same thing that temperature and humidity play a very important role in the linking process between rootstock and entris. Hartmann and Kester (1983) stated that the temperature of air affects the formation of parenchymal cell cell constituents of callus formed due to injection. Optimum temperature $27^{\circ} \mathrm{C}$ $29^{\circ} \mathrm{C}$, temperature higher than $29^{\circ} \mathrm{C}$ causes the formation of excess parenchyma cells, but the cell walls are thin so easily damaged. At temperatures below $20^{\circ} \mathrm{C}$, the formation of slow callus and below $15^{\circ} \mathrm{C}$ callus will not be formed at all.

\subsection{Percentage of growing bud $(\%)$}

Data of the observation of the percentage of live budding success. Based on the research that has been done, obtained the combination of treatment data as in Table 1, while the results of manual calculations can be seen in Appendix 6 .

Table 1: Average of growing bud

\begin{tabular}{lccc}
\hline Treatments & \multicolumn{2}{c}{ Days } & $\begin{array}{c}\text { Persentage of growing bud } \\
(\mathbf{\%})\end{array}$ \\
\hline m1u1 & $\mathbf{D A B})$ & $\mathbf{4 5}(\mathbf{D A B})$ & $100 \%$ \\
m1u2 & $\sqrt{ }$ & $\sqrt{ }$ & $100 \%$ \\
m1u3 & $\sqrt{ }$ & $\sqrt{ }$ & $100 \%$ \\
m1u4 & $\sqrt{ }$ & $\sqrt{ }$ & $100 \%$ \\
m1u5 & $\sqrt{ }$ & $\sqrt{ }$ & $100 \%$ \\
m2u1 & $\sqrt{ }$ & $\sqrt{ }$ & $100 \%$ \\
m2u2 & $\sqrt{ }$ & $\sqrt{ }$ & $100 \%$ \\
mu3 & $\sqrt{ }$ & $\sqrt{ }$ & $100 \%$ \\
m2u4 & $\sqrt{ }$ & $\sqrt{ }$ & $100 \%$ \\
m2u5 & $\sqrt{ }$ & $\sqrt{ }$ & $100 \%$ \\
\hline
\end{tabular}

Notes: $\mathrm{DAB}=$ day after budding

The result of observation data of the percentage of growing bud that the influence of stem age and budding method on the growing bud (Citrus Sp.) With the average percentage of rowing bud days after budding (DAB) that is $100 \%$ successful, so it can be known at each age factor of rootstock and budding method showed no significant effect on the success rate of live budding 14-45 DAB. The combination of rootstock and stem (budding) has shown a very real success, although the rootstock is different age, but the success of live budding is not hindered by age difference, in this study also age used is very diverse for example age 4, 6, 8, 10 and 12 months there is a $100 \%$ growing bud. In essence, the percentage of growing bud (\%) is not only fixed on 1 or 2 age but which must be observed on the budding of success factors such as rootstock, entres, tools used, and maintenance. At the time of the budding operation there will be a linkage of the upper and lower stems going through a two-stage process, which enlarges and divides the new cambium cell connecting the upper cavity and the rootstock, the formation of the vascular tissue that drains nutrients and water from the rootstock to the upper stem, the new cambium cell and vascular. So that the different ages are generally said to have an effect on the percentage of successful live budding (\%) is in fact what we know is the fertility between the rootstock and the top stem (entrys). 


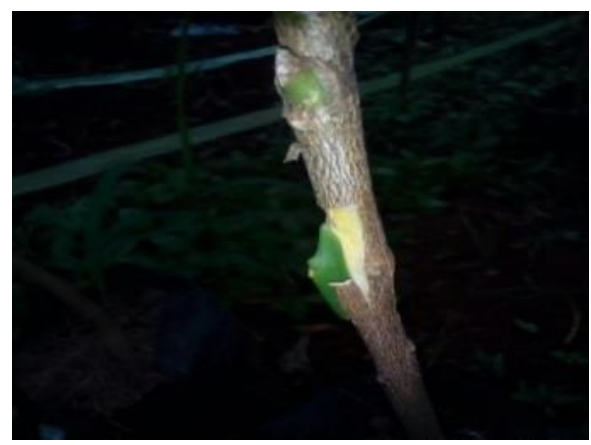

A

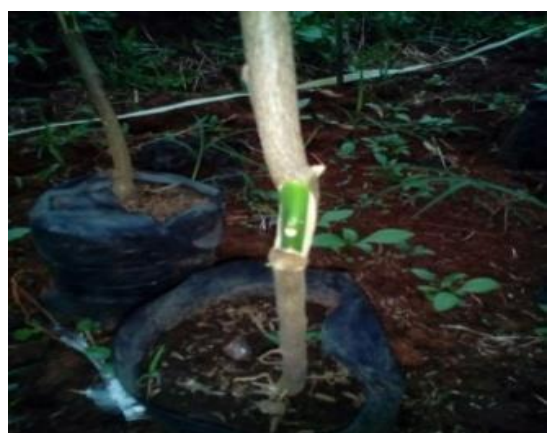

B

Figure 1: Persentage of Growing Bud: (a) T-Metode (T-budding); (b) Chip Metode (Chip Budding)

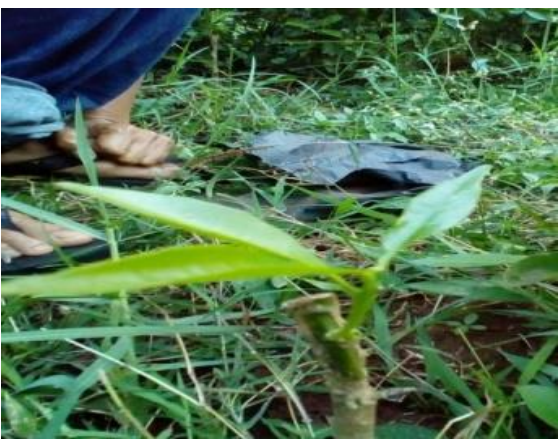

A

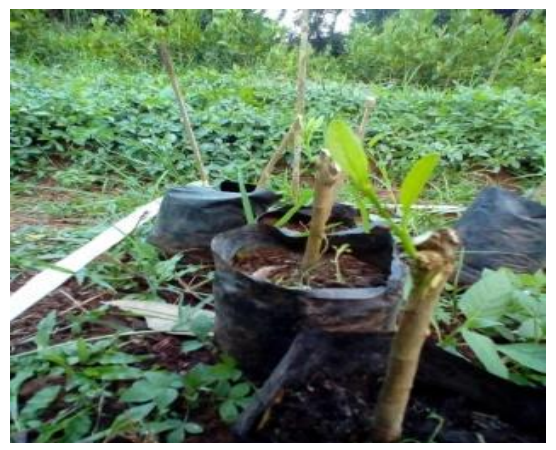

B

Figure 2: Persentage of Growing Bud 45 DAB: (a) Metode T (T bud); (b) Metode Sisip (Chip Bud)

The growing of bud is largely determined by some of the crop compatibility mechanisms themselves, such as physiological properties, boichemistry and anatomical systems simultaneously. Thus it can be seen that live budding (Figures 3 and 4) and what if there is failure or death is not solely caused by the treatment of rootstock and budding method, but can be caused by environmental factors such as humidity, sunlight, or any other temperature can also be caused from technical factors when the implementation of the budding itself. Optimal temperature and humidity will also enhance the formation of fine tissue, which is necessary for the success of a patch (budding). The temperature required in the paste is between $7.2-32^{\circ} \mathrm{C}$, when the temperature is less than $7.2^{\circ} \mathrm{C}$ the callus formation will be slow. When more than $32^{\circ} \mathrm{C}$ the callus formation is also slow and can kill cells on the connection. The optimum temperature at the connection is 25$30^{\circ} \mathrm{C}$. The attachment requires high humidity, when low humidity will be dry, and inhibit or block the callus formation in the joint because many cells in the connection die. Sunlight effect on the timing of the pengempelan going. Therefore, the connection should be done in the morning or evening at a time when the sun is not strong enough to radiate and light. Overheated light will also reduce the resistance of the top stem (entres) to the drought, and may damage the cambium in the connection area. Then on the technical factors affecting the success of the budding is the skill, the connecting speed is the best prevention against infectious diseases and damage to the cambium and the perfection of tools in the connection required sharpness and cleanliness of the tool, thin and flexible straps. 


\subsection{Time of start growing}

The result of observation the starting time of bud appearace as shown in the appendix 7 and the figure is as below:

\section{Figure 3: Start growing}

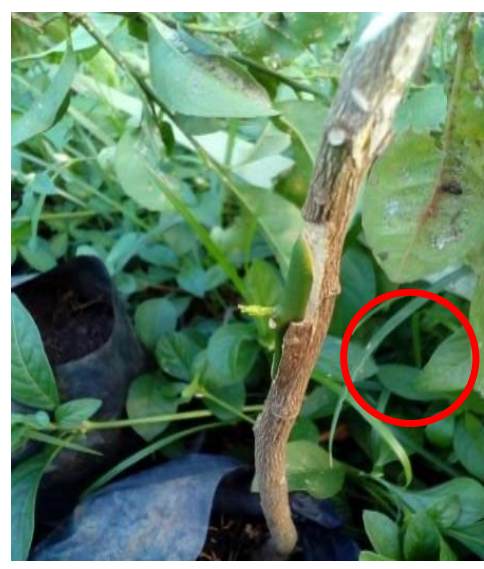

The result of observation data of the beginning time of the shoots is very diverse that is different day, seen in the data of Appendix 7. Each treatment and replication show different fluctuation. So that the observation data can be known with the average value of the initial time of bud budding buds of oranges from the influence of stem age under 6 months, which gives the average value of the initial time of shoots emerged faster $24 \mathrm{DAB}$, while the time appear shoots are slow 25 DAB which is found at the age of rootstock 10 and 12 months. Nevertheless, the average centres used with the age of the stems show the very standard shoots appear from the usual budding treatment.

Growth rate of buds appear there are several factors that influence among others the level of compatibility of rootstock and stem above, which resulted in the distribution of nutrients from the rootstock food will continue to enter the upper stem through a network that has been attached perfectly both through the roots and leaves.

According to Nahansyah (1990) in Sutami and Gusti (2009), the difference in the rate of shoot buds is thought to be due to the ability of different plants to form the budding linkage associated with the amount of callus formation speed. According to Hartmann and Kesler (1983) in Sutami and Gusti (2009). That the process of callus formation required hormones in sufficient quantities. This hormone serves to begin the process of tissue formation by using carbohydrates and sugars to shoot buds.

\subsection{High shoot $(\mathrm{cm})$}

The data of observation and analysis of the variation of the influence of the stem age and the budding method on the high parameters of citrus shoots can be seen in (Annex 8, 9, 10 and 11) (Citrus Sp.) Interaction of rootstock age and the budding method showed no significant effect and seen independently shows a marked influence (Table 2). Based on statistical data, the result of statistical analysis shows that the real suitability is consistent with the change cycle of each shoot growth time, at $30 \mathrm{DAB}$ the age of the stem does not show any significant effect, then at 35 and 40 $\mathrm{DAB}$ gives a real effect and at age $45 \mathrm{DAB}$ again does not give the effect is real, whereas in the budding method viewed based on the time 30,35, 40 and 45 DAB method showed a real effect. This is because there are several factors that affect the growth of the upper stem against the shoot height, such as the difference in age of the rootstock. Table 2 The age of the rootstock / inetrstock showed that at 6 months of age showed higher growth of shoots than the rest of the stem age, then 
from the two methods used T (T-budding) and the Chip-budding method tendency on the Chipbudding method.

Table 2: Average of stalk height

\begin{tabular}{lcccc}
\hline \multirow{2}{*}{ Treatments } & & \multicolumn{2}{c}{ Height of Stalk } & \\
& 30 DAB & 35 DAB & 40 DAB & 45 DAB \\
\hline $\mathrm{u} 1$ & $0.45 \mathrm{a}$ & $1.01 \mathrm{ab}$ & $1.51 \mathrm{ab}$ & $1.98 \mathrm{a}$ \\
$\mathrm{u} 2$ & $0.48 \mathrm{a}$ & $1.05 \mathrm{a}$ & $1.6 \mathrm{a}$ & $1.98 \mathrm{a}$ \\
$\mathrm{u} 3$ & $0.48 \mathrm{a}$ & $1.01 \mathrm{ab}$ & $1.55 \mathrm{a}$ & $1.95 \mathrm{a}$ \\
$\mathrm{u} 4$ & $0.41 \mathrm{a}$ & $0.95 \mathrm{ab}$ & $1.46 \mathrm{ab}$ & $1.91 \mathrm{a}$ \\
$\mathrm{u} 5$ & $0.4 \mathrm{a}$ & $0.88 \mathrm{~b}$ & $1.36 \mathrm{~b}$ & $1.9 \mathrm{a}$ \\
$\mathrm{m} 1$ & $0.36 \mathrm{~b}$ & $0.85 \mathrm{~b}$ & $1.36 \mathrm{~b}$ & $1.8 \mathrm{~b}$ \\
$\mathrm{~m} 2$ & $0.53 \mathrm{a}$ & $1.11 \mathrm{a}$ & $1.64 \mathrm{a}$ & $2.13 \mathrm{a}$ \\
\hline
\end{tabular}

Notes: Average figures of the same coloumn followed by the same letter are not significantly different based on Duncan test at $5 \%$

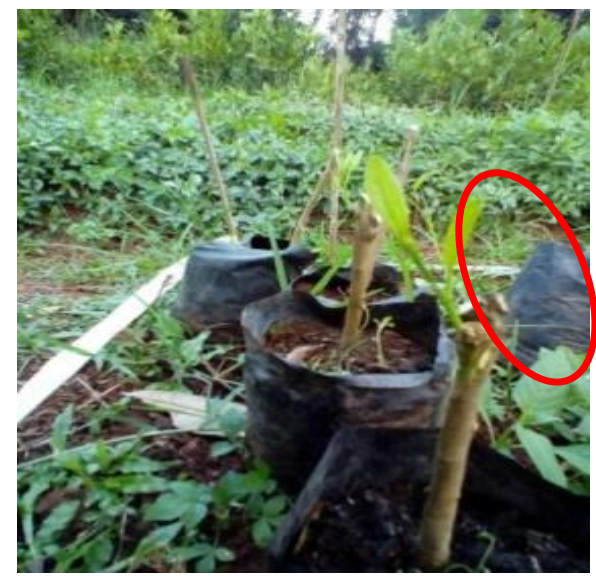

Figure 4: Length of sprout at $45 \mathrm{DAB}$

Putri et al. (2006) states that there are several factors that affect the growth of the stem on the high shoot, if viewed from the physiology of disruption of the flow of plant growth regulator (ZPT) in the plant and disturbed distribution of photosynthesis results, but also the age of rootstock used is still young not yet woody will occur damage at the time of budding, so also the age of the old rootstock will slow growth, whereas in the best method is influenced by technical factors such as the result of incision of onion rod with incision of the top bar (entres) should be appropriate because it will show the marrow between the upper stem and the rootstock through a two-stage process, namely the enlargement or division of new cambium and the formation of vascular tissue (Yuniastuti et al., 1992).

The occurrence of this discrepancy in buddy rupture shows that the influence of interstock and rootstock in inducing the appearance of stem buds is different or it can be assumed that the abscissic acid content synthesized in young leaves and cytokines is produced by the roots and transported to the tip through the xylem vessels in a state of no balanced, thus causing rupture of different buds (Sugiyatno et al., 2013).

The results of this study were significantly different from the research (Yuniastuti et al., 1992; Mohamad et al., 2013) where the top working treatment on the grape shoots did not affect the rate of growth of buds. Similarly, in the study of the use of rootstock was an effect on the appearance 
of buds. In the visible trunk, the interstock is no longer a barrier network but as a connective tissue that facilitates the physiological processes of plants either moving from the bottom up or vice versa.

\subsection{Stem diameter}

The data of observation and analysis of the variation of the influence of stem age and the budding method on the orange shoot diameter parameter can be seen in (Appendix 12 and 13) the influence of the age of rootstock and orange budding method (Citrus Sp.) Showed no significant effect on shoot bud diameter at all treatment both interactionally and independently (Table 3).

\section{Table 3: Average of stalk diameter (DAB)}

\begin{tabular}{lcc}
\hline Treatment & 40 DAB & Stalk Diameter \\
\hline u1 & $0.15 \mathrm{a}$ & 45 DAB \\
u2 & $0.16 \mathrm{a}$ & $0.2 \mathrm{a}$ \\
u3 & $0.16 \mathrm{a}$ & $0.2 \mathrm{a}$ \\
u4 & $0.11 \mathrm{a}$ & $0.2 \mathrm{a}$ \\
u5 & $0.11 \mathrm{a}$ & $0.16 \mathrm{a}$ \\
m1 & $0.12 \mathrm{a}$ & $0.15 \mathrm{a}$ \\
m2 & $0.16 \mathrm{a}$ & $0.17 \mathrm{a}$ \\
\hline
\end{tabular}

Notes: Average figures of the same coloumn followed by the same letter are not significantly different based on Duncan test at $5 \%$

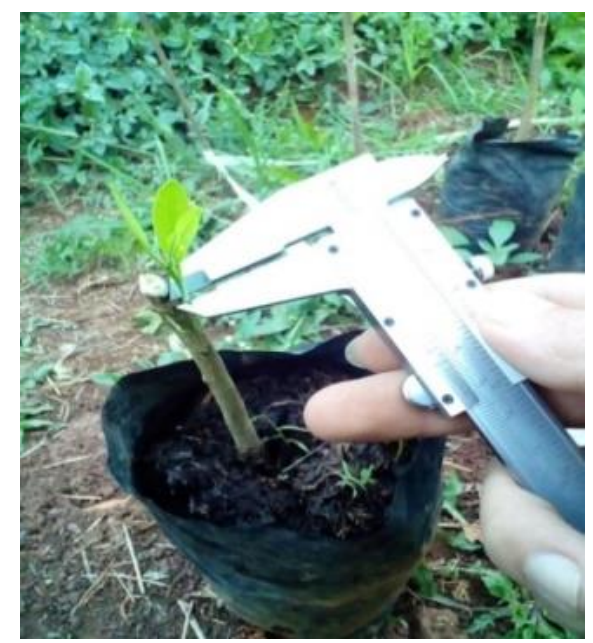

\section{Figure 5: Diameter of stalk}

Based on statistical data above indicate that the real match according to the change cycle every time the growth of shoot diameter, while the treatment of rootstock and budding method does not show the real effect either interaction or independently, but from each treatment indicates which results are best, so that at (Table 3) the age of the rootstock is best seen at 6 months of age, whereas the method is shown by the Chip-Budding method. Good growth is indicated by the ability of plants to photosynthesize more and the result of photosynthesis (carbohydrates) produced more. Carbohydrates produced more ditraslocation through phloem and can be used to spur growth including the expansion of stem cells and is indicated with a wider stem diameter. So it affects the diameter of buds to be not significantly different. This happens because there are several factors that affect, such as entris used, the activity of cambium rootstock and the hormone content of the 
rootstock. The use of non-stemed entries can improve the success of budding and shoot diameter. The growth of stem diameter occurs within the intercalar meristem of the segment, the segment extends as a result of an increase in the number of cells. Growth due to cell division occurs at the base of the segment (i.e. the intercalcal) and not the end meristem. However, the intercalar meristematic activity is distributed throughout the length of the leaf lamina, leaf sheath, and the segment at the primordia stage, with increased maturity, meristem activity moving to the basal area and then stop (Gardner et al., 1991).

\subsection{Leaf amount}

The data of observation and analysis of the variation of age influence of rootstock and budding method on orange shoot diameter parameter can be seen at (Appendix 14, 15, 16 and 17) the influence of rootstock age and orange budding method (Citrus Sp.). If seen in the interaction of rootstock age with the budding method showed no significant effect and if independently treatment of rootstock and budding method showed a real effect, the results of statistical analysis on 30, 35, 40 and $45 \mathrm{DAB}$ age of rootstock showed a real effect, whereas in the oculation method based on time 30, 35, 40 and 45 DAB showed no significant effect, but from each treatment showed which result is best, so that at (Table 3) the age of rootstock is best seen at age 6 months, while in the method shown by the method of insip (Chip-Budding).

Table 4: Average of leaf number

\begin{tabular}{ccccc}
\hline \multirow{2}{*}{ Treatments } & 30 DAB & 35 DAB & 40 DAB & 45 DAB \\
\hline $\mathrm{u} 1$ & $0.66 \mathrm{bc}$ & $1.16 \mathrm{ab}$ & $1.66 \mathrm{bc}$ & $2.66 \mathrm{bc}$ \\
$\mathrm{u} 2$ & $1.66 \mathrm{a}$ & $2.00 \mathrm{a}$ & $2.66 \mathrm{a}$ & $3.66 \mathrm{a}$ \\
$\mathrm{u} 3$ & $1.00 \mathrm{ab}$ & $1.33 \mathrm{ab}$ & $2.16 \mathrm{ab}$ & $3.00 \mathrm{ab}$ \\
$\mathrm{u} 4$ & $0.83 \mathrm{bc}$ & $0.83 \mathrm{~b}$ & $1.83 \mathrm{bc}$ & $2.83 \mathrm{bc}$ \\
$\mathrm{u} 5$ & $0.16 \mathrm{c}$ & $0.66 \mathrm{~b}$ & $1.16 \mathrm{c}$ & $2.16 \mathrm{c}$ \\
$\mathrm{m} 1$ & $0.86 \mathrm{a}$ & $1.53 \mathrm{a}$ & $1.53 \mathrm{a}$ & $2.53 \mathrm{a}$ \\
$\mathrm{m} 2$ & $1.53 \mathrm{a}$ & $2.26 \mathrm{a}$ & $2,26 \mathrm{a}$ & $3.20 \mathrm{a}$ \\
\hline
\end{tabular}

Notes: Average figures of the same coloumn followed by the same letters are not significantly different based on Duncan test at $5 \%$

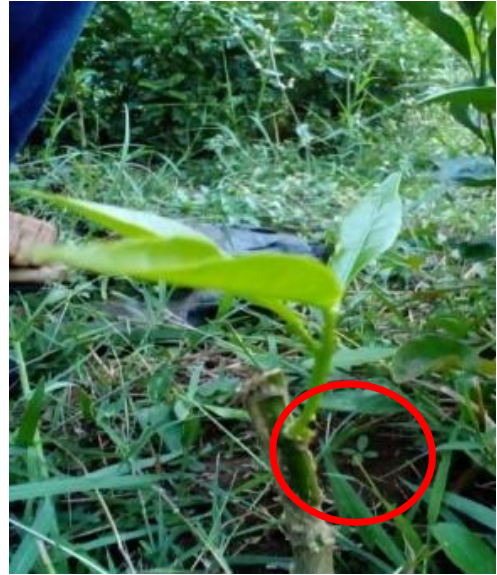

\section{Figure 6: Number of leaves at 45 DAB}

Based on the statistical data above indicate that the real match is consistent with the change cycle every time the growth of the number of leaves, while the treatment of rootstock and budding method does not give a real effect either interaction or independently, but each treatment shows the 
existence the tendency that the treated rootstock treatment is 6 months the average number of leaves more than the other aged rootstock treatment i.e. age 4, 8,10 and 12 months, while in the budding method used there is one of the most either that is shown on the method of insip (ChipBudding).

Tables 2 and 4 show that high data shoot and leaf number data. Leaf growth is closely related to the high buds because the leaves lie in the stem books. The longer the shoot, the more books are formed, so the number of leaves more and more (Bansir, 2011) in Sugiyatno (2013). The more leaves produced, the better the plant growth because the leaves are the plant organs needed for the absorption and conversion of light energy into growth and produce harvest through photosynthesis (Gardner et al., 2008; Subandi, 2014).

\section{CONCLUSION}

Conclusion Based on the results obtained from research The Effect of Lower Stem Life and The Okulation Method to the Success of Citrus Plants (Citrus sp.) Is summarized as follows: 1 . Treatment of rootstock and budding method to the success of citrus plants (Citrus sp.) Did not give ineteraksi on all parameters of observation. 2. Treatment of rootstock independently, gave a real effect on the parameters of shoot height and number of leaves, while the diameter of shoots showed no significant effect. 3. Treatment of budding method independently, giving a real effect on the shoot height parameters while the number of leaves and shoot diameter showed no significant effect.

\section{Funding: This study received no specific financial support.}

Competing Interests: The authors declared that they have no conflict of interests.

Contributors/Acknowledgement: All authors participated equally in designing and estimation of current research.

Views and opinions expressed in this study are the views and opinions of the authors, Asian Journal of Agriculture and Rural Development shall not be responsible or answerable for any loss, damage or liability etc. caused in relation to/arising out of the use of the content.

\section{References}

Bansir, L. (2011). Development of potential durian (Durio local zibethinus L.): exploration, identification. Crossing and vegetative propagation, Dissertation, Postgraduate Program Brawijaya University, Malang.

Barus, T. (2000). Large citrus physiology response (Citrus grandis (L.) Cultivar 'Cikoneng' and 'Nambangan' to budding with several types of rootstock (Graduate). Graduate Program, Bogor Agricultural University.

Buton, I. (2010). Budidaya jeruk. Blog management development information systems in rural. Bappenas Jakarta. diakses On December 20, 2012.

Devy, N. F., \& Teak, J. (2008). Propagation of 13 types of rootstock as well as 5 types of tidal orange origin in vitro. Proceedings of the National Seminar of Orange 2007.Malang (ID): Center for Horticultural Research and Development, Agency for Agricultural Research and Development. p. 168-180.

Gardner, F. P., Pearce, R. B., \& Mitchell, R. L. (2008). Cultivated physiology, translator: Herawati Susilo and Subiyanto. UI-Press, Jakarta.

Gardner, F. P., Pearce, R. B., \& Mitchel, R. L. (1991). Crop culture physiology. Printed I. Jakarta: Publisher University of Indonesia (UI.Pers).

Hartmann, H. T., \& Kester, D. E. (1983). Plant propagation principles and practices. Fourth Edition. Prentice-Hall of India Privace Limited. New Delhi. view at Google scholar / view at publisher 
Hatta, M., Hutagalung, L., \& Juhasdi dan Modding (1992). Effect of the okulation model on successful penempelan on soursop. Journal of Horticulture, 2(2), 55-58. view at Google scholar

Limbongan, J., \& Limbongan, Y. (2012). Practical hints to increase vegetative crops (Budding and Okulation). Publisher UKI Toraja Press, Makassar. 74 p. view at Google scholar

Limbongan, J., \& Djufry, F. (2013). Development of connecting technology shoots as an alternative to coconut seed propagation options development of bud budding technology as an alternative options in cocoa propagation. J. $R \&$ D Pert., 32(4), 166-172.

Mohamad, A. S., Yeni, Y., \& Opik, T. (2013). Production of biodiesel and growth of staurastrum sp. in response to CO2 induction. Asian Journal of Agriculture and Rural Development, 3(2), 67-73. view at Google scholar

Mukadasi, B. (2018). Mixed cropping systems for sustainable domestic food supply of the smallholder farming communities in nakasongola district, central uganda. Canadian Journal of Agriculture and Crops, 3(1), 42-54. view at Google scholar / view at publisher

Nahansyah, H. (1990). Tingkat kompatibilitas okulasi pada beberapa kultivar durian bibit unggul. FakultasPertanian Universitas Lambung Mangkurat. Banjarbaru. Hal, 7-15. view at Google scholar

Nurzaini, H. (1997). Fruit plants oxidation technique. CULTURE Magazine No. 13 Years V.

Obinna-Echem, P. C., \& Torporo, C. N. (2018). Physico-chemical and sensory quality of tigernut (cyperus esculentus)-coconut (cocos nucifera) milk drink. Agriculture and Food Sciences Research, 5(1), 23-29. view at Google scholar / view at publisher

Prasetyo, H. (2009). Study on the age of rootstock in two kinds of citrus propagation system. Gritek, 17(5), 908-917.

Prastowo, N., \& Roshetko, J. M. (2006). Technique of seedling and vegetative propagation of fruit plants. World Agroforestry Center (ICRAF) and Winrock International. Bogor, Indonesia.

Pratomo, A. G., Sugiyarto, M., \& Rosmahani, L. (2010). Kaji applied durian superior clonalization technology in Watulimo, Trenggalek. Proceedings of Seminar Nasional Hortikultura 2010, Indonesian Horticulture Association, pp. 58-69.

Putri, L. A., Susanto, S., \& Purwoko, B. S. (2006). Tanggap fisiologis fase vegetatif jeruk besar Cikoneng dan Nambangan pada beberapa jenis batang bawah. Journal of Scientific Agriculture, 41(1), 35-42. view at Google scholar

Samekto, H., Supriyanto, A., \& Kristianto, D. (1995). Influence of age and size of seeds to the growth of cuttings of one strip bottom of japansche itroen. Journal of Horticulture 5(1), $25-$ 29.

Samson, J. A. (1980). Tropical Friuts. Longman group limited. New York. 64-99.

Soelarso, B. (1996). Aquaculture-Free Cultivation. Kanisius, Yogyakarta.

Subandi, M., Eri, M., \& Ari, S. (2018). The crossing effect of dragon fruit plant caltivars (Hylocereus Sp.) on Yield. International Journal of Engineering \& Technology, 7(2,29), 762-765. view at Google scholar / view at publisher

Subandi, M. (2014) Comparing the local climate change and its effects on physiological aspects and yield of ramie cultivated in different biophysical environments. Asian Journal of Agriculture and Rural Development, 4(11), 515-524. view at Google scholar

Subandi, M., Setiati, Y., \& Mutmainah, N. H. (2017). Suitability of corcyra cephalonica eggs parasitized with trichogramma japonicum as intermediate host against sugarcane borer chilo auricilius. Bulgarian Journal of Agricultural Science, 23(5), 779-786. view at Google scholar

Sugiatno, S., \& Hamim, H. (2009). Influence of age of rootstock and level of shading at jatropha curcas 1) Jurnal Agrotropika, 14(1), 23-28.

Sugiyatno, A., Setyobudi, L., Maghfoer, M., \& Supriyanto, A. (2013). Growth response of tangerine plant batu 55. on some interstocks through top working methods (growth responses of mandarin cv batu 55 on several interstocks used in top working method), J. Hort., 23(4), 329-338. 
Suharsi, K. T., \& Sari, A. D. P. (2013). Growth of citrus nobilis orange eyelashes on various medicinal medium and rough lemon (c. jambhiri) (development of citrus nobilis scion on various growing media and age of citrus jambhiri rootstock). Journal Ilmu Pertanian Indonesia (JIPI), 18(2), 97-101.

Supriyanto, A., \& Setiono, B. (2006). Evaluation the Performance of the Vegetative Growth of 10 Commercial Citrus Varieties in 4 Varieties of Rootstock in Sambas, West Kalimantan. Proceedings of The National Seminar on Citrus Tropika Indonesia, Horticulture Research and Development Center. Agency for Agricultural Research and Development, p. 212-220.

Susanto, S., Suketi, K., \& Rachmawati, L. (2004). Penampilan Pertumbuhan Jeruk Besar (Citrus grandis (L.) Osbeck) CV. Cikoneng pada Beberapa Interstock. Indonesian Journal of Agronomy), 32(2), 7-11. view at Google scholar

Sutami, A., M., \& Gusti, M. S. (2009). Pengaruh umur batang bawah dan panjang entris terhadap keberhasilan sambungan bibit jeruk siam Banjar label biru. Agroscientiae, 2(16), 146-154. view at Google scholar / view at publisher

Yuniastuti, S., Soegito, P., \& Rebin, S. (1992). Combination of upper and lower stem on grape breeding with okulation. Journal of Horticulture, 2(1), 19-22. 